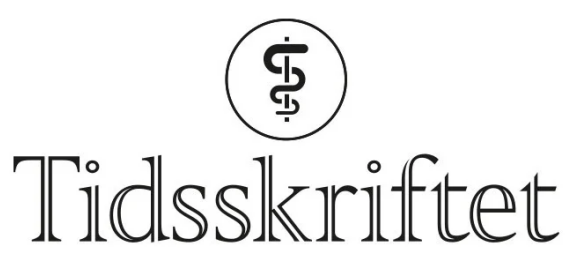

DEN NORSKE LEGEFORENING

\title{
Covid-19 - mildt forløp hos barn
}

DEBATT

CHANDRA SEKHAR DEVULAPALLI

chandev@gmail.com

Chandra Sekhar Devulapalli er dr.med., spesialist i barnesykdommer og rådgivende overlege i NAV arbeid og ytelser Kristiania.

Forfatteren har fylt ut ICMJE-skjemaet og oppgir ingen interessekonflikter.

\section{Svært få barn har testet positivt i covid-19-utbruddet. Dette kan tyde på at barn enten får milde symptomer eller at færre blir smittet.}

Covid-19-smitteutbruddet som startet i Kina i desember 2019, kan gi luftveisinfeksjon hos mennesker. Rundt $80 \%$ av de smittede har kun fått mild sykdom, viser en studie fra Journal of the American Medical Association (JAMA) (1). I studien undersøkte man de første 45000 tilfellene av covid-19-smittede i Kina. Resultatene viser at kun $1 \%$ av de smittede var i alderen 1-9 år. Det er ingen dødsfall knyttet til viruset i denne aldersgruppen. Ytterligere $1 \%$ av de smittede var i alderen 10-19 år. En annen studie fra JAMA indikerer at median alder for covid-19-pasienter er 49-56 år og at tilfeller hos barn har vært sjeldne (2)

Det rapporteres i Norge per 20. mars om 65 covid-19-smittede barn i alderen o-19 år, hvorav 51 er i alderen 10-19 år. Antall smittede barn tilsvarer omtrent 3,3\% av alle covid-19-smittede i Norge (3).

\section{Perinatal sykdom}

Ifølge nyhetssaker er to nyfødte barn smittet, ett i Kina og ett i Storbritannia. I det første tilfellet testet moren positivt for covid-19 før hun fødte (4.). I det andre tilfellet var moren innlagt på sykehus rett før fødselen med mistenkt lungebetennelse, som senere viste seg å være covid-19 (5). Det er uklart hvordan sykdommen ble overført - i livmoren eller etter fødselen. En kinesisk studie har vist at perinatal infeksjon med covid-19 kan ha uheldige effekter på nyfødte og forårsake problemer som for tidlig fødsel, luftveisbesvær, trombocytopeni ledsaget av unormal leverfunksjon og til og med død (ㅁ$)$.

\section{Andre typer koronavirus}


Er det barnebesparende mønsteret vanlig for andre sykdommer med koronavirus? At svært få barn har testet positivt i dette utbruddet, er i samsvar med andre koronavirusutbrudd i nyere historie, som sars og mers. Alvorlig akutt luftveissyndrom (sars) spredte seg i Hongkong og deretter over hele verden mars-juni 2003, forårsaket av sarsassosiert koronavirus (sars-CoV). Blant over 1700 smittede individer var kun 6,9\% under 18 år, med en dødelighet på o \%. Stockman og medarbeidere rapporterte at pasienter som var 12 år eller yngre hadde mildere sykdom og at det var mindre sannsynlig at eldre barn ble innlagt på intensivavdeling (.7.).

\section{«Barn har en tilsynelatende minimal risiko for å utvikle covid-19 og praktisk talt ingen risiko for et dødelig forløp»}

I en retrospektiv analyse av Midtøsten respirasjonssyndrom (mers) spredt i 2012, var bare $2 \%$ av tilfellene hos barn (모). Under mersutbruddet i 2016 skrev World Journal of Clinical Paediatrics at viruset forekom sjelden hos barn, men at grunnen til denne lave utbredelsen ikke var kjent (9).

Dette viser tydelig at tre forskjellige akutte luftveissykdommer med koronavirus utviklet som epidemi i de siste årene har vist en redusert tilbøyelighet til å ramme barn.

\section{Barn er lite utsatt}

Hvorfor det er slik, er fortsatt uklart. Er barn absolutt beskyttet mot infeksjon eller bare mot risiko for å utvikle sykdommen etter infeksjon? Er barna kryssbeskyttet av å ha møtt andre typer av koronavirus? Koronavirus er et av de vanligste virusene som invaderer lungene, i likhet med rhinovirus, respiratorisk syncytialvirus og influensa. Småbarn og skolebarn er mer utsatt for luftveisinfeksjoner med dråpesmitte og nærkontakt. Denne aldersgruppen er ofte smittet under de årlige utbruddene av sesonginfluensa, med et gjennomsnitt på 20-30\% av den pediatriske befolkningen (10 $)$. Det kan tenkes at virusindusert immunrespons med påfølgende vevsskade kan være mindre uttalte hos barn (11).

Ut fra det vi vet i dag, kan det tyde på at barn enten får milde symptomer eller blir smittet $\mathrm{i}$ mindre grad. Det er så langt ikke vist at barn med kronisk sykdom får alvorlig forløp av covid-19. Selv om vi ikke vet hvor massivt denne sykdommen vil spre seg og påvirke samfunnet, kan vi prøve å berolige befolkningen om barns reelle risiko. Barn har en tilsynelatende minimal risiko for å utvikle covid-19 og praktisk talt ingen risiko for et dødelig forløp.

\section{LITTERATUR}

1. Wu Z, McGoogan JM. Characteristics of and important lessons from the coronavirus disease 2019 (COVID-19) outbreak in China. JAMA 2020;323. doi:10.1001/jama.2020.2648. [PubMed][CrossRef]

2. Del Rio C, Malani PN. 2019 novel coronavirus-Important information for clinicians. JAMA 2020; 323: 1039-40. [PubMed][CrossRef]

3. Folkehelseinstituttet. Status koronasmitte fredag 20. mars 2020. https://www.fhi.no/nyheter/2020/status-koronasmitte-20-mars-2020/ Lest 20.3.2020.

4. Coronavirus: Newborn becomes youngest person diagnosed with virus. BBC 6.2.2020. https://www.bbc.com/news/world-asia-china-51395655 Lest 22.3.2020.

5. Murphy S. Newborn baby tests positive for coronavirus in London. The Guardian 14.3.2020. https://www.theguardian.com/world/2020/mar/14/newborn-baby-tests-positive-for-coronavirus-inlondon?CMP=share_btn_link Lest 22.3.2020.

6. Zhu H, Wang L, Fang C et al. Clinical analysis of 10 neonates born to mothers with 2019-nCoV pneumonia. Transl Pediatr 2020; 9: 51-60. [PubMed][CrossRef] 
7. Stockman LJ, Massoudi MS, Helfand R et al. Severe acute respiratory syndrome in children. Pediatr Infect Dis J 2007; 26: 68-74. [PubMed][CrossRef]

8. Azhar EI, Lanini S, Ippolito G et al. The Middle East Respiratory Syndrome Coronavirus - A continuing risk to global health security. Adv Exp Med Biol 2017; 972: 49-6o. [PubMed][CrossRef]

9. Al-Tawfiq JA, Kattan RF, Memish ZA. Middle East respiratory syndrome coronavirus disease is rare in children: An update from Saudi Arabia. World J Clin Pediatr 2016; 5:391-6. [PubMed][CrossRef]

10. Principi N, Esposito S. Severe influenza in children: incidence and risk factors. Expert Rev Anti Infect Ther 2016; 14: 961-8. [PubMed][CrossRef]

11. Caselli D, Aricò M. 2019-nCoV: Polite with children! Pediatr Rep 2020; 12: 8495. [PubMed][CrossRef]

Publisert: 24. mars 2020. Tidsskr Nor Legeforen. DOI: 10.4045/tidsskr.20.0231

(C) Tidsskrift for Den norske legeforening 2023. Lastet ned fra tidsskriftet.no 26. april 2023. 